\title{
PERBANKAN SYARIAH: SEBUAH KAJIAN KEPUASAN PELAYANAN NASABAH DI KOTA PEKANBARU
}

\author{
Boy Syamsul Bakhri ${ }^{1}$, Daharmi Astuti ${ }^{2}$, \& Khairunnisa $^{3}$ \\ ${ }_{1,2}^{2}{ }^{3}$ Program Studi Ekonomi Syariah, Universitas Islam Riau \\ Email : bsb_fai@fis.uir.ac.id, daharmi_astuti@fis.uir.ac.id, khairunnisa1564@gmail.com
}

\begin{abstract}
ABSTRAK
Penelitian ini didasari oleh perbankan syariah di Kota Pekanbaru yang saling berupaya dalam memberikan pelayanan yang berkualitas kepada nasabahnya. Namun sebelum itu, penting juga dikaji pengetahuan nasabah pada produk dan fasilitas layanan di perbankan syariah, alasan nasabah memilih bank syariah, serta alasan nasabah memanfaatkan kedua jenis bank (syariah dan konvensional). Hasil penelitian menemukan bahwa masih banyak nasabah bank syariah yang tidak mengetahui tentang produk spesifik bank syariah seperti produk musyarakah, produk mudharabah, produk ijarah, serta jasa rahn. Hasil penelitian juga menemukan bahwa alasan agama merupakan faktor utama bagi nasabah dalam memilih bank syariah. Adapun faktor kemudahan akses untuk ke lebih banyak cabang merupakan alasan utama nasabah memanfaatkan kedua jenis bank. Akhirnya, hasil penelitian ini menemukan bahwa sebagian besar nasabah bank syariah puas terhadap berbagai macam aspek pelayanan yang diberikan bank syariah, adapun lima aspek pelayanan dengan tingkat kepuasan nasabah tertinggi adalah keramahan staf bank syariah, nama dan citra bank syariah, kecakapan karyawan bank syariah, kerahasiaan data nasabah bank syariah, serta berbagai macam fasilitas yang ditawarkan oleh bank syariah.
\end{abstract}

Kata kunci : Kepuasan Layanan, Perbankan Syariah, Kota Pekanbaru.

\begin{abstract}
This research is based on Islamic banking in Pekanbaru City which each other in providing quality services to its customers. But before that, it is also important to examine customer knowledge on products and service facilities in Islamic banking, reasons customers choose Islamic banks, and reasons customers use both types of banks (sharia and conventional). The results of the study found that there are still many Islamic bank customers who do not know about specific Islamic bank products such musyarakah products, mudharabah products, ijarah products, and rahn services. The results also found that religious reasons are the main factor for customers in choosing of Islamic banks.The factor of ease of access to miore branches is the main reason customers use both types of banks. Finally, the results of the study found that the most Islamic bank customers are satisfied with various aspects of the services provided by Islamic banks, while the five service aspects whith the highest level of customer satisfaction are Islamic bank staff friendliness, Islamic bank name and image, Islamic bank employee skills, confidentially Islamic bank customer data, as well as various kinds of facilities offered by Islamic banks.
\end{abstract}

Keywords : Services Satisfaction, Islamic Banking, Pekanbaru City. 


\section{PENDAHULUAN}

Berfungsi sebagai lembaga intermediasi, sektor perbankan syariah di kota Pekanbaru harus mampu memperoleh kepercayaan masyarakat sebagai lembaga keuangan yang memiliki kredibilitas yang baik. Dengan demikian perbankan syariah dituntut untuk memiliki daya saing sebagai upaya terwujudnya citra yang baik kepada pangsa pasarnya.

Oleh karena itu bank syariah harus peka terhadap kepuasan nasabahnya. Kepuasan nasabah merupakan salah satu yang harus tetap dipertahankan oleh bank syariah ditengah dinamika persaingan dengan perbankan konvensional yang kompetitif. Kepuasan nasabah bank syariah akan dapat diwujudkan dengan memaksimalkan pengalaman menyenangkan, serta meminimalkan pengalaman yang tidak menyenangkan yang dirasakan oleh nasabah. Kepuasan nasabah pula akan berdampak pada terciptanya rintangan beralih, biaya beralih, dan loyalitas pelanggan.

Berdasarkan pemaparan tersebut maka penelitian ini dilakukan dengan mengangkat judul Perbankan Syariah: Sebuah Kajian Kepuasan Pelayanan Nasabah di Kota Pekanbaru.

\section{TINJAUAN PUSTAKA \\ Pengertian Bank Syariah}

Berdasarkan Undang-Undang No. 21 Tahun 2008 tentang Perbankan Syariah dijelaskan bahwa Bank Syariah merupakan bank yang menjalankan kegiatan usahanya berdasarkan prinsip syariah dan menurut jenisnya terdiri atas Bank Umum Syariah (BUS) dan Bank Pembiayaan Rakyat Syariah (BPRS). Sedangkan Bank Umum Syariah (BUS) adalah bank syariah yang dalam kegiatannya memberikan jasa dalam lalu lintas pembayaran. Kemudian yang dimaksud dengan Bank Pembiayaan Rakyat Syariah (BPRS) adalah bank syariah yang dalam kegiatannya tidak memberikan jasa dalam lalu lintas pembayaran. Unit Usaha Syariah yang selanjutnya disebut UUS adalah unit kerja dari kantor pusat Bank Umum Konvensional yang berfungsi sebagai kantor induk dari unit yang menjalankan kegiatan usaha berdasarkan Prinsip Syariah. Menurut Susyanti (2016), bank syariah adalah bank yang berasaskan pada asas kemitraan, keadilan, transparansi dan universal serta melakukan kegiatan usaha perbankan berdasarkan prinsip syariah. Sedangkan Marimuthu et al, (2010) mengatakan bahwa fungsi dan operasional dari bank syariah didasarkan pada aturanaturan syariah, dan semua kegiatan bisnis yang dilakukan bank syariah harus sesuai dengan ketentuan syariah.

\section{Produk dan Fasilitas Layanan Perbankan Syariah}

Naser et al, (2013) mengidentifikasi beberapa produk dan fasilitas yang dapat diberikan oleh perbankan syariah diantaranya rekening giro, deposito, musyarakah, mudharabah, murabahah, ijarah, qard, letter of credit $(L / C)$, jual beli valuta asing, rahn, dan bank garansi.

\section{Kriteria Pemilihan Bank Syariah}

Naser et al, (2013) mengkaji faktor-faktor yang melatar belakangi nasabah dalam memilih perbankan syariah diantaranya, hanya alasan agama, hanya alasan keuntungan, alasan agama dan keuntungan, saran dari kerabat, saran dari teman, krisis keuangan terakhir membuktikan bahwa lebih aman berurusan dengan bank syariah, layanan online yang efektif, layanan SMS yang efektif, kredibilitas bank syariah, kerahasiaan bank syariah, lokasi cabang bank syariah, rendahnya biaya layanan, efektifitas bank syariah dalam menyelesaikan transaksi, berbagai macam fasilitas yang ditawarkan oleh bank syariah, kualitas saran yang diberikan oleh karyawan bank syariah, reputasi bank 
syariah, kepercayaan terhadap manajemen bank syariah, kepercayaan pada Dewan Pengawas Syariah, keramahan staf bank syariah, dan bank syariah menawarkan fasilitas yang sama dengan bank konvensional namun bank syariah juga memperhatikan prinsip-prinsip syariah.

\section{Faktor-faktor Memanfaatkan Kedua Jenis Bank}

Naser et al, (2013) juga mengukur alasan yang melatarbelakangi nasabah dalam memanfaatkan kedua jenis perbankan (perbankan syariah dan perbankan konvensional) antara lain bank syariah tidak menawarkan beberapa produk/fasilitas sebagaimana yang ditawarkan oleh bank konvensional, bank syariah tidak menawarkan banyak produk/ fasilitas sebagaimana yang ditawarkan oleh bank konvensional, jam buka bank syariah yang terbatas, membuka dua rekening memberi peluang untuk mendiversifikasi investasi, dan kedua jenis bank ini memiliki jumlah cabang yang terbatas, dan dengan membuka dua rekening dapat memberikan akses ke lebih banyak cabang.

\section{Kepuasan Nasabah Terhadap Pelayanan Perbankan Syariah}

Naser et al, (2013)
mengidentifikasi faktor-faktor yang dapat mempengaruhi kepuasan nasabah terhadap pelayanan yang diberikan oleh perbankan syariah diantaranya saran yang diberikan oleh karyawan bank syariah, kecakapan karyawan bank syariah, tingkat kualifikasi karyawan bank syariah, kepercayaan pada Dewan Pengawas Syariah, kepercayaan pada manajemen bank syariah, biaya layanan yang ditawarkan bank syariah, jumlah cabang dari bank syariah, jam buka bank syariah, efisiensi dan kecepatan bank syariah dalam menyelesaikan transaksi, kerahasiaan nasabah, berbagai macam fasilitas yang ditawarkan, nama dan citra dari bank syariah, keramahan staf bank syariah, kesesuaian pada furnitur bank syariah, fasilitas parkir yang disediakan untuk nasabah bank syariah, efisiensi dalam menangani masalah melalui layanan telepon, desain arsitektur bank syariah, desain penataan internal bank syariah, pengiklanan produk yang telah ada dari bank syariah, pengiklanan produk baru dari bank syariah, konseling yang disediakan, ketersediaan dana, dan biaya layanan untuk cek.

\section{Pengertian Kepuasan Konsumen}

Menurut Kotler (1997) dalam Lupiyoadi (2014), kepuasan adalah tingkat perasaan dimana seseorang menyatakan hasil perbandingan atas kinerja produk jasa yang diterima dengan yang diharapkan. Menurut Akbar et al, (2019), kunci dari kepuasan nasabah adalah menyesuaikan antara harapan nasabah dengan kinerja bank itu sendiri. Kemudian, menurut Junaedi et al, (2012), kepuasan nasabah ditentukan oleh persepsi nasabah atas kinerja jasa dalam memenuhi harapan nasabah.

\section{Pengertian Kualitas Pelayanan}

Kualitas menurut ISO 9000 adalah "degree to which a set of inherent characteristics fulfils requirements" kualitas merupakan derajat yang dicapai oleh karekteristik yang inheren dalam memenuhi persyaratan. Dilanjutkan dengan persyaratan dalam hal ini ialah "need or expectation that is stated, generally implied or obligatory" dimana kebutuhan atau harapan yang dinyatakan biasanya tersirat (Lupiyoadi, 2014). Sedangkan pelayanan menurut Wirajatmi (1996) dalam Mulyawan (2016), merupakan aktivitas atau manfaat yang ditawarkan organisasi atau perorangan kepada konsumen atau dalam bisnis sering disebut customer (yang dilayani) yang bersifat tidak berwujud. Menurut Lewis dan Booms (1983) yang dikutip dalam Tjiptono (2009), kualitas layanan diartikan sebagai ukuran seberapa bagus 
tingkat layanan yang diberikan mampu sesuai dengan ekspektasi pelanggan.

\section{Kualitas Pelayanan Dalam Perspektif Islam}

Menurut Othman \& Owen (2001) yang dikutip dalam Putra \& Herianingrum (2014), konsep kualitas pelayanan dalam perspektif Islam adalah bentuk evaluasi kognitif dari konsumen atas penyajian jasa oleh perusahaan jasa yang menyandarkan setiap aktivitasnya kepada nilai-nilai moral dan sesuai kepatuhan yang telah dijelaskan oleh syariat Islam. Menurut Othman dan Owen (2001) dimensi kualitas pelayanan terdiri atas kepatuhan, jaminan, keandalan, berwujud, empati, dan ketanggapan.

\section{Konsep Operasional}

Konsep operasional penelitian ini dapat dilihat pada tabel di bawah ini:

Tabel 1. Konsep Operasional

\begin{tabular}{|c|c|c|}
\hline Konsep & Dimensi & Indikator \\
\hline $\begin{array}{c}\text { Kepuasan Pelayanan } \\
\text { Nasabah }\end{array}$ & $\begin{array}{c}\text { Kepuasan nasabah } \\
\text { terhadap pelayanan } \\
\text { perbankan syariah }\end{array}$ & $\begin{array}{l}\text { 1. Saran yang diberikan oleh } \\
\text { karyawan bank syariah } \\
\text { 2. Kecakapan karyawan bank } \\
\text { syariah } \\
\text { 3. Tingkat kualifikasi karyawan } \\
\text { bank syariah } \\
\text { 4. Kepercayaan pada Dewan } \\
\text { Pengawas Syariah } \\
\text { 5. Kepercayaan pada manajemen } \\
\text { bank syariah } \\
\text { 6iaya layanan yang ditawarkan } \\
\text { bank syariah } \\
\text { 7. Jumlah cabang dari bank } \\
\text { syariah } \\
\text { 8. Jam buka bank syariah } \\
\text { 9. Efisiensi dan kecepatan bank } \\
\text { syariah dalam menyelesaikan } \\
\text { transaksi } \\
\text { 10. Kerahasiaan nasabah } \\
\text { 11. Berbagai macam fasilitas yang } \\
\text { ditawarkan } \\
\text { 12. Nama dan citra dari bank } \\
\text { syariah } \\
\text { 13. Keramahan staf bank syariah } \\
\text { 14. Kesesuaian pada furnitur bank } \\
\text { syariah } \\
\text { 15. Fasilitas parkir yang } \\
\text { disediakan untuk nasabah bank } \\
\text { syariah } \\
\text { 16. Efisiensi dalam menangani } \\
\text { masalah melalui layanan } \\
\text { telepon } \\
\text { 21. Konseling yang disediakan } \\
\text { 17. Desain arsitektur bank syariah } \\
\text { 18. Desain penataan internal bank } \\
\text { syariah } \\
\text { 19. Pengiklanan produk yang telah } \\
\text { ada dari bank syariah } \\
\text { 20. Pengiklanan produk baru dari } \\
\text { bank syariah }\end{array}$ \\
\hline
\end{tabular}




\section{Sumber : Data Olahan, 2020}

\section{METODE PENELITIAN}

\section{Tempat dan Waktu Penelitian}

Penelitian ini dilakukan pada nasabah beberapa Bank Umum Syariah di Kota Pekanbaru yang dilakukan pada bulan September hingga bulan Desember tahun 2020.

\section{Metode Pengumpulan Data}

Teknik pengumpulan data pada penelitian ini menggunakan angket yang diberikan langsung kepada responden dilapangan. Angket adalah teknik pengumpulan data yang dilakukan dengan cara memberikan seperangkat pertanyaan atau pernyataan kepada orang lain yang dijadikan responden untuk dijawabnya (Suryani dan Hendryadi, 2015). Kemudian untuk pengukuran indikatorindikator selanjutnya menggunakan skala Likert. Skala Likert merupakan skala yang digunakan untuk mengukur sikap, pendapat dan persepsi seseorang atau kelompok terkait suatu kejadian ataupun gejala sosial (Riduwan, 2014).

\section{Metode Analisis Data}

Penelitian ini menggunakan teknik analisis data statistik deskriptif. Statistik deskriptif merupakan statistik yang menggambarkan fenomena atau data sebagaimana dalam bentuk tabel, grafik, frekuensi, rata-rata ataupun bentuk lainnya (Suryani dan Hendryadi, 2015). Distribusi frekuensi menurut Suharyadi dan Purwanto (2008), dalam Suryani dan Hendryadi (2015) adalah pengelompokan data ke dalam beberapa kategori yang menunjukkan banyaknya data dalam setiap kategori, dan setiap data tidak dapat dimasukkan ke dalam dua atau lebih kategori.

\section{HASIL DAN PEMBAHASAN}

\section{Pengetahuan Nasabah pada Produk dan Fasilitas Layanan Perbankan Syariah}

Hasil penelitian menunjukkan bahwa sebagian besar nasabah mengetahui tentang produk-produk dan fasilitas layanan perbankan pada umumnya yang juga ditawarkan di bank meskipun tidak banyak nasabah yang menggunakannya. Namun mayoritas nasabah bank syariah di Kota Pekanbaru masih banyak yang tidak mengetahui tentang produk-produk spesifik dan layanan yang ditawarkan oleh bank syariah, misalnya produk musyarakah, produk mudharabah, dan produk ijarah.

\section{Faktor-faktor Nasabah Memilih Bank Syariah}

Alasan nasabah memilih bank syariah di Kota Pekanbaru berdasarkan hasil penelitian adalah karena alasan agama, keramahan staf bank syariah, adanya prinsip-prinsip syariah yang tetap diperhatikan oleh bank syariah, lokasi cabang dari bank syariah, serta faktor kepercayaan terhadap manajemen bank syariah.

Dalam penelitian Khattak dan
Kashif Ur-Rehman (2010) juga
menemukan bahwa alasan agama
merupakan faktor utama nasabah memilih
bank syariah di Pakistan. Sedangkan
dalam penelitian lainnya yang dilakukan
oleh Naser et al, (2013) di Kuwait, salah
satu faktor utama yang menjadi alasan
nasabah memilih bank syariah adalah
kepercayaan pada manajemen bank
syariah, faktor ini sejalan dengan yang
ditemukan dalam penelitian ini.


Faktor-faktor Nasabah Memanfaatkan Kedua Jenis Bank

Mayoritas responden dalam penelitian ini merupakan nasabah dari kedua jenis bank yaitu bank syariah dan bank konvensional. Dengan demikian berdasarkan hasil penelitian, dapat disimpulkan bahwa faktor penting yang menjadi alasan nasabah bank syariah di Kota Pekanbaru memanfaatkan kedua jenis bank (bank syariah dan bank konvensional) dikarenakan masih terbatasnya jumlah cabang antara kedua jenis bank, sehingga dengan membuka rekening di kedua jenis bank dapat memberikan akses bagi nasabah ke lebih banyak cabang.

Hasil penelitian ini sejalan dengan yang ditemukan oleh Naser et al, (2013) di Kuwait, bahwa salah satu faktor utama yang menjadi alasan nasabah memilih memanfaatkan kedua jenis bank di Kuwait dikarenakan keterbatasan jumlah cabang dari kedua jenis bank, sehingga dengan nasabah membuka dua rekening dapat memberikan akses ke lebih banyak cabang

\section{Kepuasan Nasabah Terhadap Pelayanan Perbankan Syariah}

Tabel berikut menampilkan tanggapan nasabah terkait hal tersebut:

Tabel 2. Tingkat Kepuasan Nasabah pada Pelayanan Bank Syariah

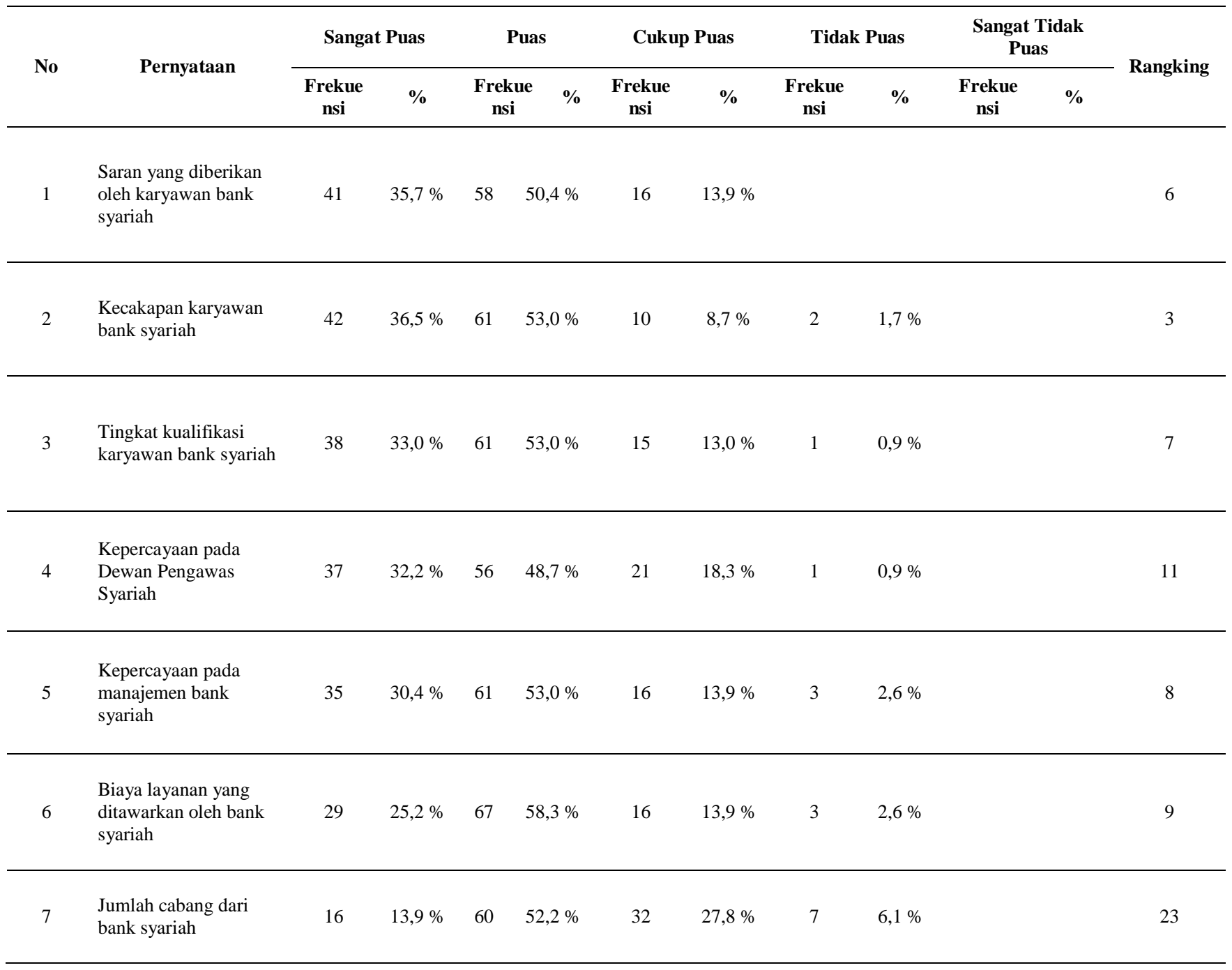


Efisiensi dan

kecepatan bank

syariah dalam

menyelesaikan

23

$20,0 \% \quad 70 \quad 60,9 \% \quad 18$

$15,7 \% \quad 3$

$2,6 \%$

$0,9 \%$

12

transaksi

10 Kerahasiaan data

nasabah bank syariah

45

$39,1 \% \quad 57 \quad 49,6 \%$

13

$11,3 \%$

4

11 fasilitas yang

ditawarkan oleh bank

syariah

$30,4 \% \quad 66 \quad 57,4 \%$

13

$11,3 \%$

$0,9 \%$

5

syariah

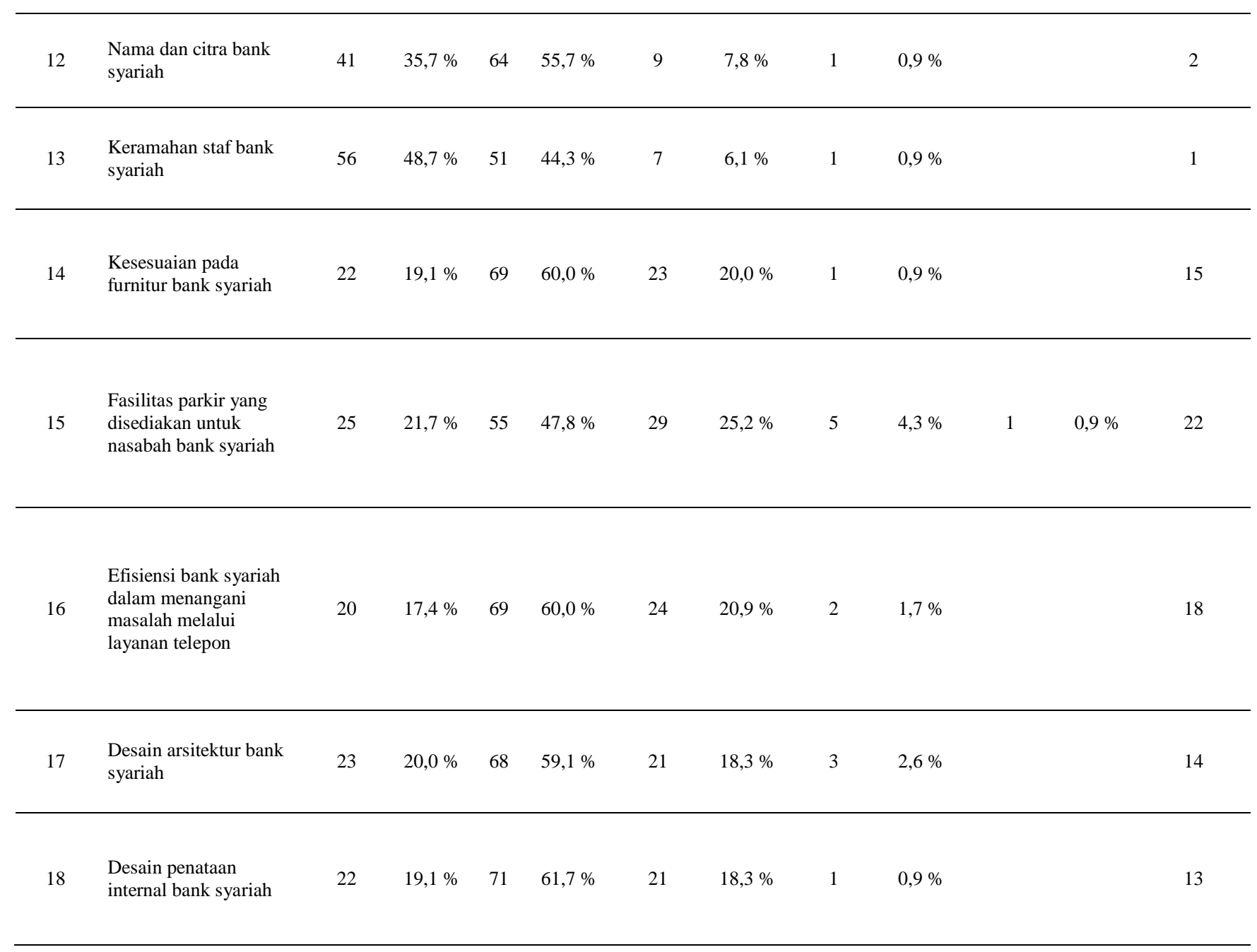




\begin{tabular}{|c|c|c|c|c|c|c|c|c|c|c|}
\hline 19 & $\begin{array}{l}\text { Pengiklanan produk- } \\
\text { produk yang telah ada } \\
\text { dari bank syariah }\end{array}$ & 24 & $20,9 \%$ & 64 & $55,7 \%$ & 26 & $22,6 \%$ & 1 & $0,9 \%$ & 19 \\
\hline 20 & $\begin{array}{l}\text { Pengiklanan produk- } \\
\text { produk baru dari bank } \\
\text { syariah }\end{array}$ & 21 & $18,3 \%$ & 67 & $58,3 \%$ & 25 & $21,7 \%$ & 2 & $1,7 \%$ & 20 \\
\hline 21 & $\begin{array}{l}\text { Konseling yang } \\
\text { disediakan oleh bank } \\
\text { syariah }\end{array}$ & 17 & $14,8 \%$ & 74 & $\begin{array}{c}64,3 \\
\%\end{array}$ & 23 & $20,0 \%$ & 1 & $0,9 \%$ & 17 \\
\hline 22 & $\begin{array}{l}\text { Ketersediaan dana } \\
\text { pada bank syariah }\end{array}$ & 22 & $19,1 \%$ & 69 & $60,0 \%$ & 23 & $20,0 \%$ & 1 & $0,9 \%$ & 16 \\
\hline 23 & $\begin{array}{l}\text { Biaya layanan untuk } \\
\text { cek dibank syariah }\end{array}$ & 25 & $21,7 \%$ & 70 & $60,9 \%$ & 20 & $17,4 \%$ & & & 10 \\
\hline
\end{tabular}

\section{Sumber: Data Olahan Angket, 2020}

Berdasarkan hasil penelitian dapat diketahui bahwa terdapat lima aspek pelayanan bank syariah yang memiliki tingkat kepuasan nasabah tertinggi di Kota Pekanbaru yaitu pada keramahan staf bank syariah, nama dan citra bank syariah, kecakapan karyawan bank syariah, kerahasiaan data nasabah bank syariah, serta berbagai macam fasilitas yang ditawarkan bank syariah.

Hasil penelitian ini sejalan dengan yang ditemukan oleh Naser et al, (1999) yang juga menemukan bahwa nasabah bank syariah di Jordan juga memiliki tingkat kepuasan tertinggi pada aspek nama dan citra dari bank syariah, kerahasiaan data nasabah, berbagai fasilitas yang ditawarkan bank syariah, kecakapan karyawan bank syariah. Kemudian dalam penelitian lain Naser et al, (2013) di Kuwait juga menemukan bahwa nasabah bank syariah di Kuwait memiliki tingkat kepuasan yang tinggi pada nama dan citra bank syariah, dan kerahasiaan data nasabah bank syariah, di samping aspek-aspek lain seperti ketersediaan dana pada bank syariah, kepercayaan pada Dewan Pengawas Syariah, dan kepercayaan pada manajemen bank syariah.

\section{KESIMPULAN}

Dalam penelitian ini sebagian besar nasabah bank syariah masih banyak yang tidak mengetahui tentang produkproduk yang ditawarkan oleh bank syariah. Penelitian ini juga mengidentifikasi ada lima faktor utama yang menjadi alasan nasabah memilih bank syariah yaitu semata-mata hanya karena alasan agama, keramahan staf bank syariah, bank syariah menawarkan fasilitas yang sama dengan bank konvensional namun bank syariah juga memperhatikan prinsip-prinsip syariah, lokasi cabang bank syariah, serta alasan kepercayaan terhadap manajemen bank 
syariah. Kemudian, penelitian ini juga menunjukkan bahwa alasan yang paling mendasari nasabah memanfaatkan kedua jenis bank adalah dikarenakan keterbatasan jumlah cabang yang dimiliki oleh kedua bank, sehingga dengan nasabah membuka dua rekening dapat memberikan akses bagi nasabah ke lebih banyak cabang. Akhirnya, penelitian ini juga menemukan bahwa lima aspek pelayanan yang memiliki tingkat kepuasan nasabah bank syariah tertinggi yaitu pada keramahan staf bank syariah, nama dan citra bank syariah, kecakapan karyawan bank syariah, kerahasiaan data nasabah bank syariah, serta berbagai fasilitas yang ditawarkan bank syariah.

\section{REFERENSI}

Akbar, Y. Rahmat., Zain, Irsyadi., \& Nuraini, Putri. 2019. Analisis Dimensi Service Marketing Mix Sebagai Pengukur Kepuasan Nasabah Bank Syariah di Pekanbaru. Jurnal Tabarru': Islamic Banking and Finance, 2 (2), p. 1-15.

Junaedi, Achmad Tavip., Hadiwidjojo, Djumilah., Troena, Eka Afnan., \& Triyuwono, Iwan. 2012. Analisis Pengaruh Kualitas Pelayanan, Keadilan, dan Kepuasan Nasabah Terhadap Loyalitas Nasabah Bank Syariah (Studi pada Nasabah Bank Syariah di Provinsi Riau). Jurnal Aplikasi Manajemen, 10(1), p. 161-176.

Khattak, Naveed Azeem., \& Kashif-UrRehman, 2010, Costumer Satisfaction and Awareness of Islamic Banking System in Pakistan, African Journal of Business Management, 4(5), p. 662-671.
Lupiyoadi, Rambat. 2014. Manajemen Pemasaran Jasa. Salemba Empat. Jakarta.

Marimuthu, Maran., Jing, Chan Wai., Gie, Lim Phei., Mun, Low Pey., \& Ping, Tan Yew. 2010. Islamic Banking: Selection Criteria and Implications. Global Journal of Human Social Science, 10(4), p. 52-62.

Mulyawan, Rahman. 2016. Birokrasi dan Pelayanan Publik. Unpad Press. Sumedang.

Naser, Kamal., Salem, Athmar., \& Nusaibah, Rana. 2013. Costumers Awareness and Satisfaction of Islamic Banking Products and Services : Evidence from the Kuwait Finance House. International Journal of Marketing Studies, 5(6), p. 185-199.

Naser, Kamal., Jamal, Ahmad., \& AlKhatib, Khalid. 1999. Islamic Banking: A Study of Costumer Satisfaction and Preference in Jordan, International Journal of Bank Marketing, 17(3), p. 135150.

Othman, Abdul Qawi., \& Owen, Lyyn. 2001. Adopting and Measuring Costumer Service Quality (SQ) In Islamic Banks: A Case Study in Kuwait Finance House. Journal International of Islamic Financial Service, 3(1).

Putra, Rizky Pratama., \& Herianingrum, Sri. 2014. Pengaruh Kualitas Pelayanan Islami Terhadap Kepuasan dan Loyalitas Nasabah Bank BRI Syariah Surabaya. Jurnal Ekonomi 
2021, Jurnal Tabarru' : Islamic Banking and Finance 4 (2) : 541 - 550

Syariah Teori dan Terapan, 1(9), p. 622-635.

Riduwan. 2014. Pengantar Statistika Sosial. Alfabeta. Bandung.

Suryani dan Hendryadi. 2015 Metode Riset Kuantitatif : Teori dan Aplikasi Pada Penelitian Bidang Manajemen dan Ekonomi Islam. Kencana. Jakarta.

Susyanti, Jeni. 2016. Pengelolaan Lembaga Keuangan Syariah. Empat Dua. Malang.

Tjiptono, Fandy. 2009. Service Management Mewujudkan Layanan Prima. Andi. Yogyakarta. 